\title{
кИДОНь В.І.
}

\section{ОПЕРАТИВНА ОБСТАНОВКА НАПЕРЕДОДНІ ПРОВЕДЕННЯ КИЇВСЬКОЇ СТРАТЕГІЧНОЇ НАСТУПАЛЬНОЇ ОПЕРАЦІї 1943 p.}

Операції радянських військ на київському напрямку восени 1943 року становлять значний теоретичний i практичний інтерес. У статті висвітлюеться оперативна обстановка напередодні проведення Київської стратегічної операції 1943 року, а саме: здійснено аналіз фізико-географрічних умов району проведення операції, надано склад військ, співвідношення сил та засобів протиборчих сторін, моральнопсихологічний стан військ, а також визначаеться роль партизанського pyxy.

Ключові слова: Воронезький фронт, 1-й Український фронт, битва за Дніпро, форсування Дніпра, Київська стратегічна наступальна операція, звільнення Києва, 1943 рік.

Постановка проблели та ї̈ актуальність. Правдиве об'єктивне висвітлення подій минулого $е$ необхідною умовою правильного сприйняття історичного досвіду, який ми та наші нащадки можемо засвоїти з уроків Другої світової війни. Операції радянських військ на київському напрямку восени 1943 р. становлять значний теоретичний i практичний інтерес. Для їх правильного висвітлення необхідно здійснити ретельний аналіз оперативної обстановки напередодні проведення Київської стратегічної операції 1943 року.

Аналіз попередніх досліджень $i$ публікаиій. Треба зазначити, що питанням підготовки та проведення Київської стратегічної операції 1943 року присвячений значний масив історичної літератури. Особливо цінні свідчення военачальників обох воюючих сторін, які особисто здійснювали заходи щодо планування Київської стратегічної наступальної операції та управління військами в ході бойових дій. Таку інформацію можна

Кидонь Василь Іванович, здобувач, Національна академія оборони України імені Івана Черняховського, м. Київ.

(C) Кидонь B.I., 2017 
знайти у мемуарах Г. Жукова, К. Москаленка, Е. Манштейна [1-3]. На жаль, через передчасну загибель не залишив нам спогадів командувач 1-го Українського фрронту М. Ватутін. Однак ми маємо нагоду скористатися зібраними про його діяльність біографрічними матеріалами [4]. Серед наукових воєнно-історичних праць вирізняються короткий оперативний нарис за редакцією С. Платонова «Наступление 1-го Украинского (Воронежского) фрронта на киевском направлении в 1943 году» та сучасна синтетична праця В. Гончарова «Битва за Днепр. 1943 год», що складається 3 нарисної частини, аналізу чисельності бойового складу радянських військ станом на 1 листопада 1943 року, статистики втрат тощо $[5,6]$. Сучасні вітчизняні історики проявляють постійний інтерес до теми визволення Києва у 1943 році. Про це в черговий раз засвідчили результати Всеукраїнської наукової конференції до 70-річчя визволення Києва від нацистських загарбників, видання монографічних пращь Інститутом історії України НАН України, публікацї в науковому журналі Верховної Ради України тощо [7-9].

Однак питанням всебічного дослідження, комплексного аналізу та цілісного висвітлення оперативної обстановки, що склалась на теренах України на початок осені 1943 року, в наукових працях попередників належної уваги не приділялося. Автори обмежувалися лише окремими зауваженнями з цих питань.

Мета $i$ завдання дослідження. Отже, предметом наукового пошуку автора цієї статті став комплексний аналіз оперативної обстановки напередодні проведення Київської стратегічної наступальної операції 1943 р.

Виклад основного матеріалу дослідження. Наступ 1-го Українського фрронту на київському напрямку у вересніжовтні 1943 р. займає важливе місце в історичній битві за Дніпро. Вона складалася з ряду стратегічних, фронтових i армійських наступальних та оборонних операцій. Особливе місце за своїми масштабами i результатами належить стратегічній наступальній операції 3 визволення Києва. 
Загальному наступу Червоної Армії у серпні-грудні 1943 року передували успішні дії в Курській битві, яка відкрила нові перспективи боротьби 3 гітлерівцями. Контрнаступ Червоної Армії розгорнувся на фронті від Великих Лук до Чорного моря. Одночасно бойові дії велися на західному, південно-західному і південному стратегічних напрямках. Радянські війська стрімко просувалися на захід.

Війська вермахту були вимушені перейти до стратегічної оборони на усьому радянсько-німецькому фронті. Ворог чіплявся за вигідні рубежі місцевості, використовуючи для цієї мети перш за все водні перешкоди, проводячи короткі, але сильні контрудари своїми оперативними резервами. Цими ударами німці розраховували не дати радянським військам повною мірою використати стратегічний успіх, який намітився після розгрому противника в липні-серпні в районі Орла, Белгорода, Харкова i на Донбасі. Німці прагнули утримати захоплену територію i зупинити наступ радянських військ на рубежах Велиж, Дорогобуж, Брянськ, Суми та річок Північний Донець, Міус. За умов, якби не вдалося утриматися на цих рубежах, противник розраховував закріпитися на рубежах річок Десна, Сож, Дніпро, Молочна. На усіх цих рубежах гітлерівцями посилено велися оборонні роботи [6, с. 87].

Особливо велике значення німецьке командування надавало рубежу Дніпра - головної частини «Східного валу». «Східний вал» (OSTWALL) - стратегічний оборонний рубіж німецьких військ. Його основою мала стати річка Дніпро у середній течії, південніше p. Молочна, північніше - рубіж по лінії р. Сож, міст Орша, Вітебськ, Псков. У вересні 1943 р. він був розділений на два рубежі: «Пантера» - оборонний рубіж у смузі груп армій «Північ» $\mathrm{i}$ «Центр» та «Вотан» - рубіж у смузі груп армій «Південь» та «А» [9, с. 59].

Німецьке керівництво планувало перейти до позиційної оборони, утримання захоплених територій, знекровленню 
наступаючих радянських військ. Оборонна лінія складалася 3 протитанкових ровів, розвинутої системи траншей, опорних пунктів, довготривалих вогневих точок.

Дніпро був серйозною природною перешкодою для військ:швидкість його течії доходила місцями до 2 метрів в секунду, ширина - до 3,5 кілометра, а глибина - до 12 метрів. Високий стрімкий правий берег панує на тривалій відстані над лівим, низьким. «Швидше Дніпро потече назад, - заявив після падіння Харкова Гітлер, ніж росіяни здолають його - цю потужну водну перешкоду 700-900 м шириною, правий берег якої є ланцюгом безперервних дотів, природну неприступну фрортецю» [4, c. 192].

Командир 48-го німецького танкового корпусу генерал Кнобельсдорф зазначав: «Дніпро планувався як лінія опору ще після падіння Сталінграда навесні 1943 року. Його велика ширина, низький східний берег і високий крутий західний, здавалося, повинні були стати непереборним бар'єром для росіян» [10, с. 110].

Бажання утримати позиції біля Дніпра було пов'язане зі збереженням багатих районів півдня України, що мали велике економічне значення для Німеччини. Україна для німців мала бути важливою сировинною базою. Крах позицій по Дніпру позбавляв Німеччину українського хліба, залізної руди Криворіжжя, марганцю і кольорових металів Запоріжжя і Нікополя.

Війська Центрального, Воронезького i Степового фронтів отримали завдання на швидке висування до Дніпра і захоплення плацдармів на його правому березі. Центральний фрронт під командуванням К. Рокоссовського, що діяв на північній ділянці смуги наступу, мав завдати удару лівим крилом на Чернігів і далі на захід. Степовий фронт на чолі з I. Коневим мав завдання вийти до ділянки від Кременчука до Дніпропетровська. Між Центральним i Степовим дронтами наступав Воронезький фрронт. 
Район бойових дій 1-го Українського (Воронезького) фрронту в Київській операції обмежувався, із заходу залізницею Єльск, Овруч, Коростень, Житомир, Бердичів, 3 півночі - лінією Чернігів, Єльск, 3 півдня - лінією Черкаси, Біла Церква, Бердичів і зі сходу - лінією Ніжин, Прилуки, Пирятин, Черкаси.

У смузі наступу Воронезького фрронту відходили 3 правого фрлангу з'єднання німецької 4-ї танкової армії, а 3 лівого фрлангу - з'єднання 8-ї армї групи армій «Південь». Командував групою армій «Південь» фельдмаршал Манштейн. В групу армій «Південь» входили 8 армія у складі 3-го, 11-го, 42-го армійських та 47-го танкових корпусів, 1 танкова армія у складі 3-го, 24-го, 46-го танкових і 59-го армійських корпусів, 4 танкова армія у складі 16-ї, 29-ї моторизованих дивізій, 6-го, 7-го румунських та 4-го армійських корпусів. Також до складу групи армій «Південы» входили 213-та, 444-та, 454-та охоронні дивізї [11, с. 366].

Основне угруповання танкової армії відходило на Київ. Противник не міг швидко перекинути на правий берег Дніпра всі свої сили, бойову техніку і матеріальні запаси. Для Е. Манштейна ця операція була найскладнішою і найнебезпечнішою за всю війну. 1000-кілометровий фронт був прорваний на багатьох ділянках. У цих умовах сили чотирьох армій потрібно було з боями відвести назад на кілька сотень кілометрів, не втрачаючи згуртованості і без паніки. Тому Е. Манштейн одну армію залишив для оборони, а три інші переправлялись через Дніпро.

Німці посилено прикривали київську переправу. Вони прагнули організовано перекинути всі свої сили на правий берег річки. На рубежі Пухівка, Гоголів, Бориспіль, Кайлів вели стримуючі бої 213-та охоронна дивізія, 68-ма, 88-ма, 75-та піхотні дивізї, частина сил 82-ї і 327-ї піхотних дивізій німців. Бровари займала 291-ша піхотна дивізія. У районі Києва переправлялися через Дніпро 183-тя і 340-ва піхотні дивізіі. Також прибули 3 інших ділянок фрронту 95-та і 339-та піхотні дивізї. 
Північніше Києва по правому березі Дніпра займала оборону 208-ма піхотна дивізія. Всього в районі Киева німці мали дванадцять піхотних дивізій, 3 яких шість прикривали переправи, а решта переправлялися через Дніпро i займали оборону на його правому березі. Німецькі війська в районі Києва входили до складу7-го і 13-го армійських корпусів [5, с. 22].

Біля Канева відходили з'єднання 8-ї німецької армії. Оборонні бої по лінії Ліпляве, Глемязово, Коробівка вели 24-й танковий корпус у складі 10-ї моторизованої, 57-ї, 255-ї, 112-ї і 34-ї піхотних дивізій та 12-ї штурмової бригади. На ділянці фронту від Кайлова до Ліпляве по лівому березі Дніпра німецьких військ не було. 3 Києва через Кагарлик на південь від Переяслав-Хмельницького висувалася 19-та танкова дивізія. Головні підрозділи цієї дивізї частини 34-ї піхотної дивізії з'явилися у населених пунктах Григорівка i Зарубинці i вступили в бій 3 мотопіхотою 3-ї гвардійської танкової армї радянських військ, яка переправлялася через Дніпро.

Уздовж правого берега Дніпра 3 південного сходу в напрямку на Канів рухались 7-ма танкова і 72-га піхотна дивізії німців. Всього на ділянці фрронту від Ржищева до Черкас по обох берегах Дніпра у німців було понад п'яти піхотних, одна моторизована і три танкові дивізії, 3 яких безпосередньо вели бойові дії чотири піхотні i одна моторизована дивізї.

Угруповання 8-ї німецької армї̈ в складі 3-го і 47-го танкових і 11-го армійського корпусів, які вели бої в районі Полтави, повільно відходило до Дніпра у Кременчук. У смузі Воронезького фронту перед його лівим фрлангом діяв 3-й танковий корпус у складі танкової дивізї СС «Вікінг», 6-ї танкової дивізії групи військ «Д», а також танкова дивізія СС «Мертва голова» і 223-тя піхотна дивізія зі складу 47-го танкового корпусу. Всього перед Воронезьким фрронтом у противника було близько 26 дивізій, 3 яких до 19 піхотних, одна моторизована i шість танкових. Всі ці дивізії в попередніх боях зазнали великих втрат [5, с. 23]. 
Через 6 дніпровських мостів практично без втрат було переправлено чотири армії з обслуговуючим персоналом i частиною місцевого населення Лівобережжя. Генерал Е. Раус згадував: «Однак всі наші зусилля пішли б прахом, якби росіяни правильно використали свої значні повітряні сили. Тому, як не смішно, за великим рахунком успіх нашої переправи забезпечила Червона Армія. На наш подив, радянські літаки не показувались до того часу, доки 90 відсотків наших військ, зброї і техніки не закінчили переправу» [12, с. 365].

Воронезький фрронт здійснював наступ на Київському напрямку. Згідно 3 донесенням представника Ставки Верховного Головнокомандування основна мета наступальних операцій - прорив до Дніпра 3 його фрорсуванням, захоплення та розширення плацдармів на його правому березі, для подальшого розгрому німецьких загарбників на Правобережній Україні [13].

У складі Воронезького фронту діяли 3-тя гвардійська танкова, 4-та гвардійська, 27-ма, 38-ма, 40-ва, 47-ма, 52-га армії, 2-га повітряна армія та з'єднання і частини фрронтового підпорядкування [14, с. 250].

38-ма армія наступала безпосередньо на Київ на правому крилі фрронту. На Переяслав-Хмельницький 3 виходом до Дніпра на ділянці Ржищів, Канів наступали 40-ва і 47-ма армії та 3-тя гвардійська танкова армія 3 1-м гвардійським кавалерійським корпусом. 52-га і 4-та гвардійська армії вели бої на рубежі Бригадирівка, Кузубївка, Степанівка, Волок, Диканька у взаємодії зі Степовим фронтом, наступали на південь.

38-ма армія діяла у складі 50-го, 51-го стрілецьких корпусів і 5-го гвардійського танкового корпусу. Армія вела бої 3 угрупованням противника в складі 213-ї охоронної, 68-ї, 75-ї, 82-ї, 88-ї, 291-ї, 327-ї піхотних дивізій. 240-ва і основні сили 167-ї стрілецьких дивізій вийшли до лівого берега річки Десни на ділянці Літки, Рожни i приступили до переправи через цю річку. 22 вересня 1943 р. до Дніпра в районі Переяслав-Хмельницького вийшло центральне угруповання військ фрронту [6, с. 13]. 
Першими вийшли до Дніпра частини 3-ї гвардійської танкової армії, розвідувальні підрозділи 69-ї механізованої бригади 9-го механізованого корпусу. На світанку 22 вересня батальйон мотопіхоти 69-ї механізованої бригади 9-го механізованого корпусу переправився через Дніпро і зайняв Зарубинщі. Мотострілецький батальйон 51-ї гвардійської танкової бригади 6-го гвардійського танкового корпусу також форсував Дніпро i зайняв Григорівку. Переправа цього батальйону супроводжувалася 15-хвилинним артилерійським вогневим нальотом по висотах на правому березі річки. Партизани, які діяли в цій місцевості, надали передовим частинам танкової армії істотну допомогу, виводячи їх у найбільш зручні для форсування місця i допомагаючи збирати підручні засоби для переправ.

40-ва армія вийшла до річки Дніпро на ділянці Кальне, Гусенщі, Андруші. 47-ма армія вийшла на лінію Чепілко, Богдани, Коврай-Безбородько, Ашанівка, втративши зіткнення 3 противником, що прикривав переправу в районі Канева. 27-ма армія перебувала у другому ешелоні фронту i здійснювала марш у район Переяслав-Хмельницького.

На лівому крилі фронту 52-га армія вийшла на лінію Бригадирівка, Кузубї̈ка, Пушкареве, Велика Багачка, маючи чотири дивізії в першому ешелоні і одну, без одного полку, у другому ешелоні. 4-та гвардійська армія також мала в другому ешелоні одну стрілецьку дивізію. Інші п'ять дивізій першого ешелону вийшли на лінію Мезени, Волок, Диканька. Однак танків 52-га і 4-та гвардійська армії не мали, і абсолютна перевага в танках була тут на боці німців, що мали три танкові дивізії [5, с. 23].

2-га повітряна армія мала у своєму складі 202-гу бомбардувальну авіаційну дивізію (Пе-2), 208-му нічну бомбардувальну авіаційну дивізію, 5-й штурмовий авіаційний корпус (Іл-2), 5-й винищувальний авіаційний корпус (Ла-5, Як-7, Як-9) і 10-й винищувальний авіаційний корпус (Як-7, Ла-7) [14]. 
У резерві фрронту знаходились великі артилерійські з'єднання:7-й артилерійський корпус прориву і 3-тя гвардійська мінометна дивізія (РС).

322 до 30 вересня війська Центрального фрронту у складі 61-ї, 13-ї, 60-ї армій, Степового фронту у складі 37-ї, 7-ї гв, 57-ї, 6-ї армій, Воронезького фрронту у складі 38-ї, 40-ї, 47-ї, 52-ї армії та 3-ї гв ТА, Південно-Західного фронту у складі 6-ї армії захопили 23 плащдарми на правому березі Дніпра та 2 плацдарми на р. Прип'ять. У смузі Воронезького фрронту було захоплено 9 плацдармів, два 3 яких, Лютізький та Букринський, відіграли важливу роль під час визволення столиці України [8, с. 91].

Захоплення плацдармів на західному березі Дніпра різко змінило обстановку на фрронті на нашу користь. Плани німецького командування були зірвані. Над противником нависла загроза втрати стратегічного рубежу оборони.

Природно-географрічні умови також значно впливали на хід бойових дій в операції, особливо це стосується складних і мінливих погодних умов та бездоріжжя.

Погода в районі бойових дій у другій половині вересня була переважно суха і ясна. Дощі випадали рідко, середня температура коливалася від 6-8 С тепла в ночі до 15-20 С в день. У жовтні погода також утримувалася суха. 316 по 19 жовтня йшов слабкий дощ, що різко знизив видимість i зіпсував дороги. Температура на початку місяця була порівняно високою: вночі 8-12 і вдень $18-20{ }^{\circ} \mathrm{C}$ тепла. У другій половині жовтня сталося деяке пониження температури: вночі до $0 \mathrm{C}$ i навіть дещо нижче,вдень $8-10^{\circ} \mathrm{C}$. У останні дні місяця температура вдень не перевищувала $2-4{ }^{\circ} \mathrm{C}$ тепла. Увесь місяць вранці стояли тумани,що різко обмежували видимість[5, с. 12].

Лівобережжя Дніпра $є$ плоскою лісостеповою рівниною. Ірунт у цьому районі суглинний. Після дощів по дорогах важко проїхати. Заплави річок переважно заболочені. Правобережжя річки Дніпро в описуваному районі захоплюе частину південного Полісся i Придніпровської піднесеності. Південне Полісся є 
плоскою низовиною 3 невисокими піщаними горбами. Річки течуть в низьких берегах. Ірунт піщаний, місцями супіщаний. Є багато невеликих, переважно торф'яних боліт, порослих лісом,особливо в заплавах річок.

Київщина має густу річкову мережу (177 річок завдовжки понад 10 км). Найважливіша водна артерія Дніпро (його довжина в межах області - 246 км), його головні притоки - Прип'ять, Тетерів, Ірпінь, Рось (праві); Десна і Трубіж (ліві). Більшість річок мають болотисті, важко доступні долини. Усе це унеможливлює наступальні дії військ у західному напрямку та створює сприятливі умови для оборони.

В описуваному районі були наступні залізниці: Ніжин-Київ (двоколійна магістраль), Дубни-Київ (одноколійна), Київ-Коростень (двоколійна), Київ-ФастівКазатин (двоколійна магістраль), Фастів-Житомир (одноколійна) i Золотоноша-Канів-Фастів (на ділянці Золотоноша-Миронівка одноколійна i далі двоколійна). При своєму відході німці значно зруйнували залізничні дороги, підірвали мости, зокрема, знищили усі мости через Дніпро (у Києва три, у Канева один міст), знищили зв'язок,спалили або забрали в Німеччину рухомий склад [5, c. 11$]$.

Також треба зауважити, що моральний стан учасників подій періоду війни був важливим чинником для бойових дій. Радянські війська в 1943 р. після перемог під Сталінградом та Курськом мали беззаперечну моральну перевагу над противником. Згідно зі спогадами Г. Жукова, К. Москаленка та інших остаточно закріпилися зміни ментальної полярності у протиборчих сторін: від відступаючої до наступаючої у радянських військах, й, відповідно, навпаки, у військ вермахту. Німецькими мемуаристами зазначено погіршення власного бойового духу. Підтвердженням цього є рекордна кількість військовополонених. Водночас напруженість й гострота бойових дій свідчить про запекле бажання німців воювати до кінця, що знайшло відображення у спогадах 
Г. Бідермана [13, с. 26], Б. Вінцера [14, с. 426] та інших, адже наслідки можливої поразки сприймалися як національна трагедія.

Оцінюючи оперативну обстановку напередодні Київської наступальної операщії, не можна не згадати роль партизанського руху. Український штаб партизанського руху узгоджував свої дії 3 діями військ. Прямим свідченням цього е документи з фондів ЦДАВО України. Ось одне із свідчень про ефективність дій партизан восени 1943 року: «...За даними на 22.09 .43 р., українськими партизанськими загонами пущено під укіс 20 військових ешелонів противника (зокрема на київських гілках): КиївКоростень - 8, Київ-Фастів - 6. У бойових діях і аваріях вбито 1034 німецьких офіцери і солдати ...» [15, арк. 62]. У цьому ж документі за 24 вересня 1943 р. вказано, що українськими партизанськими загонами пущено під укіс 12 військових ешелонів, у бойових діях та аваріях знищено 318 осіб противника. Дії партизан наводили жах на німецькі війська. Це все яскраво свідчить про те, який вагомий внесок зробили партизани у справу визволення Киева.

Висновки. Таким чином можна стверджувати, поперше, що напередодні проведення Київської стратегічної наступальної операції війська Воронезького фрронту звільнили велику територію Лівобережної України, захопили дев'ять плацдармів на південь та північ від Киева. Але потрібно зазначити, що загальна обстановка потребувала постійного маневрування та чіткої взаємодії військ з метою знищення затиснутих до дніпровських переправ сил противника. Воронезький фронт не до кінця використав всі можливості, що дало змогу німцям переправить свої війська через Дніпро.

По-друге, використавши неузгодженість і нерішучість дій радянського командування, Манштейн почав переправу військ через Дніпро, яка здійснилася майже без втрат. Основна частина німецьких військ встигла 
переправитися на правий берег Дніпра і розташуватися уздовж нього на добре укріплених позиціях. Вони могли легко маневрувати для перегрупування військ у будьякому напрямку по хорошій мережі доріг. Авіація противника встигла перебазуватися в мережу добре підготовлених аеродромів на правобережжі Дніпра (Київ, Васильків, Біла Церква, Миронівка та ін.).

В цілому можна стверджувати, що загальна перевага була на боці військ Воронезького фрронту. Оперативна обстановка у смузі фрронту залишалася сприятливою для прискореної переправи основних сил фронту, підготовки i проведення наступальної операції на київському напрямку. Виходячи з обстановки військове командування радянських військ вважало можливим почати наступ у найближчі дні силами свого центрального угруповання 3 лінії Ржищів-Канів.

1. Жуков Г.К. Спогади i роздуми / Георгий Константинович Жуков; [пер. 3 рос. А. Шевченка, Г. Кулінича]. - К.: Політвидав України, 1985. - 841 с.

2. Москаленко К.С. На Юго-Западном направлении: в 2 кн. / К.С. Москаленко. - М.: Воениздат, Кн. 2. 1979. - 566 c.

3. Манштейн Э. Проигранные победы. Личные записки генерала Вермахта / Эрих фон Манштейн; [пер. с с англ. Т.М. Шуликовой]. - М.: ЗАО Центрполиграф, 2009. - 575 с.

4. Захаров Ю.Д. Генерал армии Н.Ф. Ватутин / Юрий Дмитриевич Захаров. - М.: Воениздат, 1985. $192 \mathrm{c.}$

5. Наступление 1-го Украинского (Воронежского) фронта на киевском направлении в 1943 году. Краткий оперативный очерк / [Отв. ред. С.П. Платонов]. - М.: Воениздат, 1951. - 263 с.

6. Гончаров В.Л. Битва за Днепр. 1943 г.: / Владислав Львович Гончаров. - М.: АСТ 2006. - 784 с.

7. Битва за Дніпро. До 70-річчя визволення Киева від нацистських загарбників: Зб. наук. праць / Матеріали Всеукраїнської наукової конференції (Київ, 31 жовтня 2013 р.). - К.: Кабінет міністрів України, 2013. - 292 с. 
8. Грицюк В.M. Стратегічні та фрронтові операції Великої Вітчизняної війни на території України / В.М. Грицюк / ред. кол.: В.А. Смолій (голова) [та ін.] / НАН України. Ін-т історії України (Серія «Україна. Друга світова війна. 1939-1945»). - К.: Поліграфр. дільниця Ін-ту історії України НАН України, 2010. - 150 с.

9. Грицюк В.М., Лисенко О.С. Битва за Дніпро / В.М. Грицюк, О.Є. Лисенко // Віче. - 2013. - № 23. C. $59-61$.

10. Каманин Н.П. Летчики и космонавты / Николай Петрович Каманин. - М.: Политиздат, 1972. - 448 с.

11. Мюллер-Гиллебрант Б. Сухопутная армия Германии 1933-1945 / Буркхарт МюллерГиллебранд; [пер. с нем.]. - М.: Изографрус, Изд-во Эксмо, 2002. -800 с.

12. Раус Э. Танковые сражения на Восточном фронте / Эрхард Раус. - М.: АCT, 2006. - 528 с.

13. Центральный архив Министерства обороны Российской Федерации (ЦАМО РФ). - Ф. 236. Оп. 2673. - Д. 6. - Л. 17-20.

14. Боевой состав Советских войск. - М.: Воениздат, 1972. - $336 \mathrm{c.}$

15. Бидерлан Г.В. В смертельном бою. Воспоминания командира противотанкового расчета. 1941-1945/ Готтлоб Бидерман. - М.: Центрполиграф, 2005. $366 \mathrm{c.}$

16. Винцер Б. Солдат трех армий / Винцер Бруно [пер. с нем. Н.М. Гнединой и А.Е. Гнедина; отв. ред. 3.С. Шейниса]. - М.: Прогресс, 1971. - 464 с.

17. Центральний державний архів вищих органів влади України (ЦДАВО України). - Ф. 2. - Оп. 12. Спр. 215. 
Надійшла до редколегії 12.10.2016 p.

Рецензент: Ю.В. Бураков, кандидат історичних наук, доцент, провідний науковий співробітник Наукового центру Сухопутних військ, Національна академія сухопутних військ імені гетьмана Петра Сагайдачного, м. Львів.

\section{Кидонь В.И. \\ ОПЕРАТИВНАЯ ОБСТАНОВКА НАКАНУНЕ ПРОВЕДЕНИЯ КИЕВСКОЙ СТРАТЕГИЧЕСКОЙ НАСТУПАТЕЛЬНОЙ ОПЕРАЦИИ 1943 г.}

Операции советских войск на киевском направлении осенью 1943 года представляют значительный теоретический и практический интерес. В статье освещается оперативная обстановка накануне проведения Киевской стратегической операции 1943 года, а именно: осуществлен анализ фризико-географических условий района проведения операции, предоставлен состав войск, соотношение сил и средств противоборствующих сторон, морально-психологическое состояние войск, а также определяется роль партизанского движения.

Ключевые слова: Воронежский фрронт, 1-й Украинский фрронт, битва за Днепр, форсирование Днепра, Киевская стратегическая наступательная операция, освобождение Киева, 1943 год.

Kydon V.

THE OPERATIONAL ENVIRONMENT ON THE EVE OF KIEV STRATEGIC OFFENSIVE 1943

Operations of Soviet troops in the Kiev area in autumn 1943 of considerable theoretical and practical interest. In this article the operational situation on the eve of the Kiev strategic operation 1943, namely: the analysis of physiographic conditions of the transaction, given the composition of forces, the balance of forces and means warring parties, moral and psychological state of troops, and defines the role of partisan movement.

Keywords: Voronezh Front, 1-st Ukrainian Front, the battle for the Dnieper, crossing of the Dnieper, Kiev Strategic Offensive, liberation Kyiv, 1943. 